\title{
Vascular Gene Transfer of the Human Inducible Nitric Oxide Synthase: Characterization of Activity and Effects on Myointimal Hyperplasia
}

\author{
Edith Tzeng,* Larry L. Shears II,* Paul D. Robbins, ${ }^{\dagger}$ \\ Bruce R. Pitt, ${ }^{\neq}$David A. Geller,* Simon C. Watkins, ${ }^{\$}$ \\ Richard L. Simmons, ${ }^{+}$and Timothy R. Billiar* \\ Departments of *Surgery, ${ }^{\dagger}$ Molecular Genetics and Biochemistry, \\ ${ }^{\ddagger}$ Pharmacology, and ${ }^{\S}$ Cell Biology and Physiology, University of \\ Pittsburgh School of Medicine, Pittsburgh, Pennsylvania, U.S.A.
}

\begin{abstract}
Background: Nitric oxide (NO) has been shown to decrease myointimal hyperplasia in injured blood vessels. We hypothesize inducible NO synthase (iNOS) gene transfer even at low efficiency will provide adequate local NO production to achieve this goal.

Materials and Methods: A retroviral vector containing the human iNOS CDNA (DFGiNOS) was used to transfer the iNOS gene into vascular cells and isolated blood vessels to answer the following questions: can vascular endothelial and smooth muscle cells support iNOS activity and will low efficiency iNOS gene transfer suppress myointimal hyperplasia in injured porcine arteries?

Results: DFGiNOS-infected sheep pulmonary artery endothelial cells (SPAEC) expressed significant iNOS mRNA and protein, releasing nitrite levels of $155.0 \pm$ $10.7 \mathrm{nmol} / \mathrm{mg}$ protein $/ 24 \mathrm{~h}$ vs. $5.5 \pm 1.1$ by control cells. Transduced rat smooth muscle cells (RSMC) also ex-
\end{abstract}

pressed abundant iNOS mRNA and protein, but, in contrast to SPAEC, NO synthesis was dependent on exogenous tetrahydrobiopterin $\left(\mathrm{BH}_{4}\right)(291.8 \pm 10.4 \mathrm{nmol}$ nitrite/mg protein $/ 24 \mathrm{hr}$ with $\mathrm{BH}_{4}, 37.7 \pm 2.6$ without $\mathrm{BH}_{4}$ ). Only porcine arteries infected with DFGiNOS following balloon injury exhibited a 3-fold increase in total NO synthesis and a 15-fold increase in cGMP levels over control vessels in a $\mathrm{BH}_{4}$ dependent fashion, despite only a $1 \%$ gene transfer efficiency. Transfer of iNOS completely prevented the $53 \%$ increase in myointimal thickness induced by balloon catheter injury; the administration of a NOS inhibitor reversed this effect.

Conclusions: These in vitro findings suggest that vascular iNOS gene transfer may be feasible. Furthermore, a low gene transfer efficiency may be sufficient to inhibit myointimal hyperplasia following arterial balloon injury, although a source of $\mathrm{BH}_{4}$ may be required.

\section{INTRODUCTION}

Arterial wall injury initiates a cascade of events, including platelet and inflammatory cell recruitment resulting in local mitogen release, that culminates in smooth muscle migration and proliferation (reviewed in Ref. 1). This sequence of events is thought to be important in the pathogenesis of intimal hyperplasia associated with restenosis as well as atherosclerosis. Such a predictable response to vascular injury may compro-

Address correspondence and reprint requests to: Timothy R. Billiar, University of Pittsburgh, A1010 Presbyterian Hospital, Pittsburgh, PA 15213, U.S.A. mise the success of angioplasty and surgical bypass for obstructive vascular lesions. Many current experimental efforts focus on methods to minimize the local proliferative process and reduce neointima formation. Potentially efficacious agents under investigation include cytotoxic drugs, angiotensin-converting enzyme inhibitors (2), antisense oligonucleotides to block gene expression (3), and gene transfer to promote the local synthesis of antiproliferative agents $(4,5)$. If one could inhibit the proliferative response of the injured tissue, the incidence of restenosis might be significantly reduced.

A vital component of normal vascular ho- 
meostasis is endothelium-derived nitric oxide (NO). Vascular properties of nitric oxide (NO) include vasodilation $(6,7)$, prevention of platelet adhesion and activation (8), inhibition of smooth muscle proliferation (9), and prevention of leukocyte-endothelial interactions (10). Under physiologic conditions, $\mathrm{NO}$ is derived from the endothelial constitutive NO synthase (ecNOS or Type III NOS), which synthesizes small quantities of NO in a calcium- and calmodulin-dependent fashion $(11,12)$. Endothelial injury and dysfunction are common features of a number of disease processes, and the loss of NO synthetic capacity may contribute to the pathologic changes. For example, hypertensive states have been identified in which endothelium-derived NO is deficient, resulting in pathophysiologic alterations in the blood vessel $(13,14)$. NO deficiencies may also exist at sites of injury incurred by angioplasty or surgical procedures $(15,16)$. Others have reported evidence that increasing serum levels of the NOS substrate L-arginine $(17,18)$ attenuates neointima formation at sites of vascular injury. Recent results in a rat carotid injury model indicates restoring ecNOS activity at the site of injury with liposome-mediated transfection prevents neointimal hyperplasia and preserves vasoreactivity (19).

Another approach to increase local NO levels is through the transfer of a different NOS isoform, the inducible NOS (iNOS or Type II NOS), to vascular target cells such as endothelial or smooth muscle cells. Distinct from the ecNOS, iNOS synthesizes much larger quantities of NO in a sustained manner and functions independent of intracellular calcium fluxes (reviewed in Ref. 20). Therefore, even if iNOS is expressed in relatively few cells, a wide field of cells could be exposed to NO independent of external agonists needed by the ecNOS to stimulate calcium fluxes. Because of technical limitations associated with vascular gene transfer strategies, a gene effective when expressed in low abundance could have distinct advantages. In these respects, iNOS could have important advantages over ecNOS as a therapeutic tool for the treatment of restenosis. A potential pitfall of NOS gene transfer rests in the ability of targeted cells and tissues to produce the cofactor tetrahydrobiopterin $\left(\mathrm{BH}_{4}\right)(21)$, essential for the function of all NOSs. To investigate the feasibility of human iNOS gene transfer, a retroviral vector expressing both human iNOS and the neomycin phosphotransferase (Neo) selectable marker was constructed. The iNOS retroviral vector was used to stably transfer high output iNOS activity to cultured endothelial cells and vascular smooth muscle cells as well as to arterial segments in vitro. We show that endothelial cells and smooth muscle cells can be engineered to express stably an active human iNOS enzyme with differential requirements for $\mathrm{BH}_{4}$. Finally, low efficiency iNOS gene transfer to arterial segments was adequate to reduce significantly injury-induced myointimal hyperplasia.

\section{MATERIALS AND METHODS}

\section{Construction of Retroviral Vectors}

The human hepatocyte iNOS cDNA measuring $4145 \mathrm{bp}$ in length was cloned in our laboratory as previously described (22) and was subcloned into the MFG retroviral vector (23) as follows: An NcoI site was created at the ATG start codon of the iNOS cDNA with polymerase chain reaction (PCR)-directed site-specific mutagenesis, altering base pairs 205 and 206 (no amino acid changes because the ATG starts at base pair 207). The 3' primer was complementary to the sequence at base pair 1252. The iNOS cDNA (140 ng) was subjected to PCR amplification in a thermal cycler (Perkin-Elmer Cetus; Norwalk, CT, U.S.A.). The 1-kb PCR product was digested with $\mathrm{NcoI}$ and EcoRI to generate a 854-bp 5' iNOS fragment. A 3' BamHI compatible site was created at base pair 3705 (the translational stop codon is located at base pair 3666) utilizing $B c l$ linkers. The 2646 bp 3' to $E c o$ RI to $B c l$ fragment was then isolated. Ligation of the $5^{\prime}$ and $3^{\prime}$ iNOS fragments into the retroviral backbone, where an internal ribosome entry site (IRES) and a neomycin phosphotransferase (Neo) gene had been previously inserted at the $3^{\prime}$ BamHI site, yielded the DFGiNOS construct (Fig. la). The IRES permits translation of a polycistronic mRNA. The control retroviral vectors MFGlacZ and BaglacZ were previously described $(24,25)$ (Fig. $1 \mathrm{~b}$ and c). Both carry the $\beta$-galactosidase gene, while BaglacZ additionally carries the Neo gene.

\section{Production of Replication-Deficient Retrovirus}

The DFGiNOS plasmid was calcium phosphate transfected into the transient ecotropic packaging cell line BOSC23 (26). Viral supernatants were collected $72 \mathrm{hr}$ after transfection and used to infect CRIP cells (27) to generate a stable amphotropic producer cell line. CRIP cells were 
a. DFGiNOS

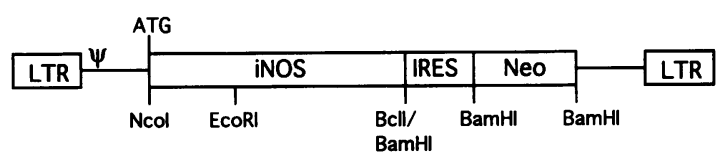

b. MFGlacZ

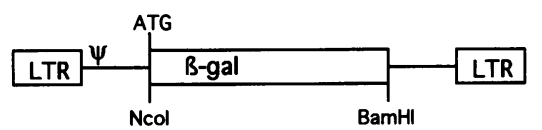

c. BaglacZ

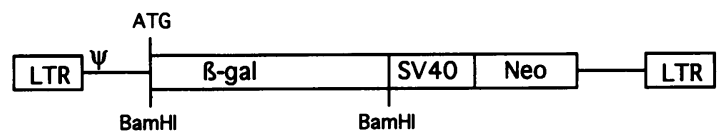

FIG. 1. Retroviral vectors

The human hepatocyte iNOS cDNA was inserted in the sense orientation into the MFG vector to yield DFGiNOS (a) utilizing the NcoI and BamHI cloning sites MFGlacZ (b) was previously constructed and does not include the Neo selectable marker. BaglacZ (c) is a retroviral vector carrying both lacZ and Neo. LTR, retroviral long terminal repeat; $\psi$, viral packaging signal; ATG, translational start codon; iNOS, human hepatocyte iNOS cDNA; IRES, internal ribosome entry site which allows translation of a polycistronic mRNA; Neo, neomycin phosphotransferase cDNA; $\beta$-gal, $\beta$-galactosidase cDNA; SV40, simian virus 40 enhancer and promoter.

incubated with BOSC23 viral supernatant with 8 $\mu \mathrm{g} / \mathrm{ml}$ polybrene (Sigma Chemical Co., St. Louis, MO, U.S.A.) and then selected with G418 (750 $\mu \mathrm{g} / \mathrm{ml}$, Geneticin, Gibco-BRL, Grand Island, NY, U.S.A.). The BOSC23 supernatant had an estimated titer of $10^{5} \mathrm{CFU} / \mathrm{ml}$. Individual G418-resistant CRIP colonies were isolated and screened for nitrite $\left(\mathrm{NO}_{2}^{-}\right)$production as an indirect measure of iNOS expression. The colonies generating the highest $\mathrm{NO}_{2}^{-}$levels were tested for virus production by the number of G418-resistant NIH3T3 colonies following infection with serial dilutions of the CRIP-DFGiNOS supernatants. The BAG mobilization assay for replication competent helper virus was performed as previously described (28).

\section{Cell Culture}

BOSC23 cells were grown in Dulbecco's modified Eagle's medium (DMEM), $10 \%$ fetal calf serum, $100 \mathrm{U} / \mathrm{ml}$ penicillin, $100 \mu \mathrm{g} / \mathrm{ml}$ streptomycin, and $4 \mathrm{mM}$ glutamine and CRIP cells in DMEM, $10 \%$ calf serum, $50 \mathrm{U} / \mathrm{ml}$ penicillin, 50 $\mu \mathrm{g} / \mathrm{ml}$ streptomycin, and $10 \mathrm{mM}$ HEPES. Sheep pulmonary artery endothelial cells (SPAEC) were isolated by collagenase digestion and grown in OPTI-MEM I (Gibco-BRL), 10\% sheep serum, $100 \mathrm{U} / \mathrm{ml}$ penicillin, $100 \mu \mathrm{g} / \mathrm{ml}$ streptomycin, 15 $\mu \mathrm{g} / \mathrm{ml}$ endothelial cell growth supplement (Collaborative Biomedical Products, Bedford, MA, U.S.A.), and $10 \mathrm{U} / \mathrm{ml}$ heparin. At the second to third passage, cells were incubated with $1,1^{\prime}$ dioctadeyl-1,3,3,3',3' -tetramethyl-indocarbocyanine perchlorate-labeled acetylated low density lipoprotein (DiIAc-LDL; Biomedical Technologies Inc., Staughton, MA, U.S.A.) and cells preferentially incorporating DiIAc-LDL were isolated by fluorescence activated cell sorting (FACstar; Becton Dickinson Immunocytometry, San Jose, CA, U.S.A.). Subcultures were routinely positive for DiIAc-LDL uptake as well as von Willebrand factor (vWF). Rat pulmonary artery smooth muscle cells (RSMCs) were isolated from left pulmonary artery explants as previously described (29). The cells were maintained in DMEM/F12 $(1: 1 \mathrm{v} / \mathrm{v}) 10 \%$ fetal calf serum, $4 \mathrm{mM} \mathrm{L-glu-}$ tamine, $100 \mathrm{U} / \mathrm{ml}$ penicillin, and $100 \mu \mathrm{g} / \mathrm{ml}$ streptomycin. The cells had the characteristic spindle shape of smooth muscle cells and were positively identified by indirect immunofluorescence staining for $\alpha$-actin and smooth musclespecific myosin. Only early passage RSMCs (passages 3-8) were utilized in the following experiments. All cell lines were grown at $37^{\circ} \mathrm{C}$ in a $5 \% \mathrm{CO}_{2} / 95 \%$ air incubator.

\section{Infection of Vascular Cells}

SPAECs and RSMCs at $50 \%$ confluence were infected for $8 \mathrm{hr}$ with either DFGiNOS or BaglacZ viral supernatant with $8 \mu \mathrm{g} / \mathrm{ml}$ polybrene and selected in G418 $(500-750 \mu \mathrm{g} / \mathrm{ml})$. Following selection, $>90 \%$ of BaglacZ-infected SPAECs and RSMCs possessed $\beta$-galactosidase activity by $\mathrm{X}$-gal staining. All cells were cultured in $0.5 \mathrm{mM}$ $\mathrm{N}^{G}$-monomethyl-L-arginine (L-NMA) to inhibit NO synthesis until $24 \mathrm{hr}$ prior to experimentation. A subgroup of SPAEC-DFGiNOS was cultured without L-NMA for $>14$ days to study the effects of sustained high level NO production. L-NMA administration did not alter cell growth or morphology.

\section{RNA Isolation and Northern Blot Analysis}

Total cellular RNA was isolated from uninfected, BaglacZ, and DFGiNOS SPAECs and RSMCs as well as SPAEC treated for $6 \mathrm{hr}$ with $1 \mathrm{mM} \mathrm{N}$ - 
acetyl-penicillamine (NAP) or S-nitroso-Nacetyl-penicillamine (SNAP; Sigma) using RNAzol B as previously described (30). Aliquots (20 $\mu \mathrm{g})$ of RNA were electrophoresed on a $0.9 \%$ agarose gel and blotted to GeneScreen (DuPontNEN, Boston, MA, U.S.A.). After prehybridization, the membranes were hybridized to a DNA probe as described (31). A 2.3-kb human iNOS cDNA fragment served as the iNOS probe while a 4.1-kb human endothelial cNOS cDNA fragment served as the ecNOS probe. $18 \mathrm{~S}$ rRNA served as a control for relative RNA loading.

\section{Cell Lysate Preparation}

Uninfected and BaglacZ- and DFGiNOS-infected SPAECs were washed and resuspended in protease inhibitor buffer (20 mM TES, pH 7.4, $2 \mathrm{mM}$ DTT, $10 \%$ glycerol, $25 \mu \mathrm{g} / \mathrm{ml}$ Antipain, $25 \mu \mathrm{g} / \mathrm{ml}$ Aprotinin, $25 \mu \mathrm{g} / \mathrm{ml}$ Leupeptin, $25 \mu \mathrm{g} / \mathrm{ml}$ Chymostatin, $50 \mu \mathrm{M}$ Phenanthroline, $10 \mu \mathrm{g} / \mathrm{ml}$ Pepstatin A) supplemented with $10 \mu \mathrm{M} \mathrm{FMN}, 10 \mu \mathrm{M}$ $\mathrm{FAD}$, and $5 \mu \mathrm{M} \mathrm{BH}$. The cells were lysed by three freeze-thaw cycles, and the cytosolic fraction was isolated by centrifugation at $100,000 \times$ $g$ for $60 \mathrm{~min}$ at $4^{\circ} \mathrm{C}$ as previously described (32). Protein concentrations were measured with the BCA protein assay (Pierce, Rockford, IL, U.S.A.). For whole cell preparations, a similar procedure was performed without the centrifugation step.

\section{Western Blot}

Cell cytosols $(100 \mu \mathrm{g})$ were electrophoresed through an $8 \%$ SDS-polyacrylamide gel and transfered to nitrocellulose membranes (Schleicher $\&$ Schuell, Keene, NH, U.S.A.) as described (33). Membranes were blocked with $5 \%$ milk/ phosphate buffered saline $/ 0.1 \%$ Tween-20 and hybridized with a monoclonal antimouse macrophage iNOS antibody (1:2000 dilution; Transduction Laboratories, Lexington, KY, U.S.A.) that detects human iNOS, followed by a goat anti-mouse IgG linked to horseradish peroxidase (Schleicher \& Schuell). Human hepatocyte cytosol isolated $14 \mathrm{~h}$ following stimulation with 5 $\mathrm{U} / \mathrm{ml}$ human ILl $\beta$ (Cistron, Pine Brook, NJ, U.S.A.), $500 \mathrm{U} / \mathrm{ml}$ human TNF $\alpha$ (Genzyme, Boston, MA, U.S.A.), $100 \mathrm{U} / \mathrm{ml}$ human IFN $\gamma$ (Amgen, Thousand Oaks, CA, U.S.A.), and $10 \mu \mathrm{g} / \mathrm{ml}$ LPS (Escherichia coli 0111:B4; Sigma) served as a positive control. The membrane was developed with ECL reagents (DuPont-NEN) and exposed to Kodak X-Omat film for 1-20 min at room temperature. For ecNOS, $25 \mu \mathrm{g}$ of whole cell preparations were electrophoresed. The primary antibody was monoclonal murine IgG against human ecNOS (1:2000 dilution; Transduction Laboratories) that detects ovine ecNOS.

\section{Assay for $\mathrm{NO}_{2}^{-}$and $\mathrm{NO}_{3}^{-}$Production}

Uninfected, BaglacZ, and DFGiNOS SPAECs and RSMCs were passaged to 6-well plates at near confluency in the presence of $0.5 \mathrm{mM}$ L-NMA. Culture medium was then replaced with fresh medium and the cells were cultured for an additional $24 \mathrm{hr}$ at which time the supernatants were assayed for accumulated $\mathrm{NO}_{2}^{-}$using the Griess reaction (31). Measurements were also performed in the presence of L-NMA $(0.5 \mathrm{mM})$ and/or $\mathrm{BH}_{4}(100 \mu \mathrm{M})$. The cells in each well were then lysed with $1 \%$ Triton X-100/25 mM Tris phosphate/2 mM EDTA/10\% glycerol and the protein concentration was quantified with the BCA protein assay. Some supernatants were also assessed for total $\mathrm{NO}_{2}^{-}$and $\mathrm{NO}_{3}^{-}$levels with a standardized HPLC assay utilizing an in-line column containing copper-coated cadmium as previously described (34).

\section{Arterial Organ Culture}

Femoral arteries were collected from anesthesized (sodium pentobarbital, $4 \mathrm{mg} / \mathrm{kg}$ ) domestic pigs through bilateral groin incisions and immediately immersed into sterile phosphate buffered saline. The adventitia was gently dissected free, and some vessels were uniformly injured with a 4-French balloon catheter inflated to 10 atmospheres for $30 \mathrm{sec}$. All arteries were opened along the long axis, divided into $1-\mathrm{cm}$-long sections, and cultured in DMEM, 20\% FCS, $100 \mathrm{U} / \mathrm{ml}$ penicillin, $100 \mu \mathrm{g} / \mathrm{ml}$ streptomycin, and $4 \mathrm{mM}$ L-glutamine at $37^{\circ} \mathrm{C}$ as previously described (35). On culture Day 5, some arterial segments were incubated with $2 \mathrm{ml}$ of either DFGiNOS or MFGlacZ viral supernatant (both titers $\sim 10^{6} \mathrm{CFU} /$ $\mathrm{ml})$ supplemented with polybrene $(8 \mu \mathrm{g} / \mathrm{ml})$ for $6 \mathrm{hr}$. Following infection, the vessels were transfered to fresh culture dishes to remove any explanted cells and were maintained in organ culture for a total of 14 days with daily media changes. After our initial observations that $\mathrm{NO}_{2}^{-}$ $+\mathrm{NO}_{3}^{-}$release from the DFGiNOS-transfected vessels was $\mathrm{BH}_{4}$ dependent, $\mathrm{BH}_{4}(100 \mu \mathrm{M})$ was supplemented on a daily basis to all the cultures. L-NMA $(0.5 \mathrm{mM})$ was added to some vessel preparations. On Day 14, culture supernatants were collected for $\mathrm{NO}_{2}^{-}+\mathrm{NO}_{3}^{-}$and cGMP determina- 
tions. cGMP levels were measured with a commercial radioimmunoassay (NEN, Boston, MA, U.S.A.).

To evaluate efficiency of MFGlacZ infection, vessel segments were fixed in $0.5 \%$ glutaraldehyde for $30 \mathrm{~min}$ and stained for $\boldsymbol{\beta}$-galactosidase activity with $\mathrm{X}$-gal. DFGiNOS segments were fixed in $2 \%$ paraformaldehyde for $1 \mathrm{hr}$ at $4^{\circ} \mathrm{C}$ and cryoprotected in $30 \%$ sucrose overnight at $4^{\circ} \mathrm{C}$. Vessels were then quick frozen with HistoFreeze-2000 (Fisher, Pittsburgh, PA, U.S.A.) and $5-\mu \mathrm{m}$ cryosections cut. Sections were mounted on glass slides, permeabilized with $2 \%$ paraformaldehyde $/ 0.1 \%$ Triton X-100, blocked with 5\% goat serum, and then incubated with the primary monoclonal antimurine iNOS antibody previously used for Western blot analysis. The antibody staining was visualized with immunoperoxidase. To measure myointimal thickness, semiserial sections were incubated for $60 \mathrm{~min}$ with rhodamine phalloidan (Molecular Probes, Inc., Eugene, OR, U.S.A.), which binds to actin. These preparations were visualized with indirect fluorescence microscopy (Nikon, FA) and recorded by a Sony DXC 930 camera linked to a computer. The myointimal thickness was quantified with the Optimas program (Optimas Corp., Seattle, WA, U.S.A.) at 25 random sites along the length of each vessel segment and calculated as the mean of all the measurements.

Some vessels were homogenized with a polytron and the RNA was extracted with RNAzol as described above. First strand cDNA synthesis was performed on $500 \mathrm{ng}$ of total RNA in a volume of $10 \mu \mathrm{l}$ with $50 \mathrm{mM}$ Tris- $\mathrm{HCl}(\mathrm{pH} \mathrm{8.3)}$, $75 \mathrm{mM} \mathrm{Kcl}, 3 \mathrm{mM} \mathrm{MgCl} 2,1.0 \mathrm{mM}$ dNTPs, $10 \mathrm{mM}$ DL-dithiothreitol, $10 \mathrm{U}$ human placental RNAse inhibitor, and $200 \mathrm{U}$ MMLV reverse transcriptase (GIBCO, Gaithersburg, MD, U.S.A.) at $37^{\circ} \mathrm{C}$ for $60 \mathrm{~min}$. cDNAs (100 ng) were combined in $50 \mu \mathrm{l}$ in $10 \mathrm{mM}$ Tris- $\mathrm{HCl}(\mathrm{pH} 8.3), 50 \mathrm{mM} \mathrm{Kcl}, 200 \mu \mathrm{M}$ dNTP, $1.5 \mathrm{mM} \mathrm{MgCl}_{2}, 100 \mathrm{pM}$ each PCR primer, and $1.25 \mathrm{U}$ Taq DNA polymerase (Perkin-Elmer Cetus) and PCR amplification carried out with denaturation at $94^{\circ} \mathrm{C}$ for $1 \mathrm{~min}$, annealing at $57^{\circ} \mathrm{C}$ for $2 \mathrm{~min}$, and elongation at $72^{\circ} \mathrm{C}$ for $3 \mathrm{~min}$ for 40 cycles. The iNOS oligonucleotide primers specifically recognize the human hepatocyte iNOS cDNA sequence and do not detect rodent sequences. The 18-bp 5' primer spanned from base pair 3426 to 3444 of the iNOS cDNA with the sequence 5'-AGGACATCCTGCGGCAGC-3' and the $3^{\prime}$ primer spanned from base pair 3724 to 3741 with the sequence 5 '-GCTTTAACCCCT CCTGTA- $3^{\prime}$. The predicted PCR product is 316 bp. PCR amplification for Neo mRNA, unique to the DFGiNOS virus, was performed as another marker for expression of the iNOS transgene $($ Neo PCR product $=728 \mathrm{bp})$. Reverse transcriptase PCR for $\beta$-actin message served as a control. The $\beta$-actin PCR product measures 652 bp. PCR products were visualized on a $1.5 \%$ agarose gel.

\section{Statistical Analysis}

Values for $\mathrm{NO}_{2}^{-}, \mathrm{NO}_{2}^{-}+\mathrm{NO}_{3}^{-}$, cGMP, and myointimal thickness are expressed as means \pm SD. The significance of differences was determined using the ANOVA test. Statistical significance was established at a $p$ value of $<0.01$.

\section{RESULTS}

\section{Generation of Retroviral Vectors}

Functional expression of the modified human iNOS cDNA in the DFGiNOS vector was tested in BOSC23 by assaying for $\mathrm{NO}_{2}^{-}$production following transfection with DFGiNOS plasmid DNA. BOSC23 transfected with DFGiNOS produced $\mathrm{NO}_{2}^{-}$levels of $35.3 \pm 2.6 \mu \mathrm{M} / 48 \mathrm{hr}$ versus $0.7 \pm$ 0.2 for cells transfected with MFGlacZ DNA $(p<$ $0.01)$. BOSC23 supernatants were used to infect CRIP cells to generate a stable amphotropic producer cell line. Following infection and G418 selection, a mixed CRIP-DFGiNOS cell population produced high levels of $\mathrm{NO}_{2}^{-}(50.9 \pm 2.8$ $\mu \mathrm{M} / 24 \mathrm{hr}$ ) when $\mathrm{BH}_{4}$ was supplemented. In the absence of exogenous $\mathrm{BH}_{4}$, however, $\mathrm{NO}_{2}^{-}$levels of only $4.7 \pm 1.0 \mu \mathrm{M} / 24 \mathrm{hr}$ were measured $(p<$ $0.01) . \mathrm{BH}_{4}$ is known to be an essential cofactor for all NOS enzymes, necessary in part for maintaining the active structural configuration of the enzyme (36,37). A G418-resistant CRIP clone was found to produce DFGiNOS virus at a titer of $5 \times 10^{6} \mathrm{CFU} / \mathrm{ml}$ and exhibited $\mathrm{NO}_{2}^{-}$production of $\sim 50 \mathrm{nmol} / 10^{6}$ cells $/ 24 \mathrm{hr}$ in the presence of $\mathrm{BH}_{4}$. Viral supernatant from this clone tested free of replication competent virus and was used in all subsequent experiments. Despite the reported inhibitory effect of $\mathrm{NO}$ on the replication of some viruses (38), no difference was detected in viral titers from BOSC23-DFGiNOS grown with or without the NOS inhibitor L-NMA (both $\sim 10^{5}$ $\mathrm{CFU} / \mathrm{ml}$ ). These results demonstrate that a functional iNOS retroviral vector can be generated and that certain cells may lack the $\mathrm{BH}_{4}$ synthesis required to support $\mathrm{NO}$ synthesis wherein $\mathrm{BH}_{4}$ 

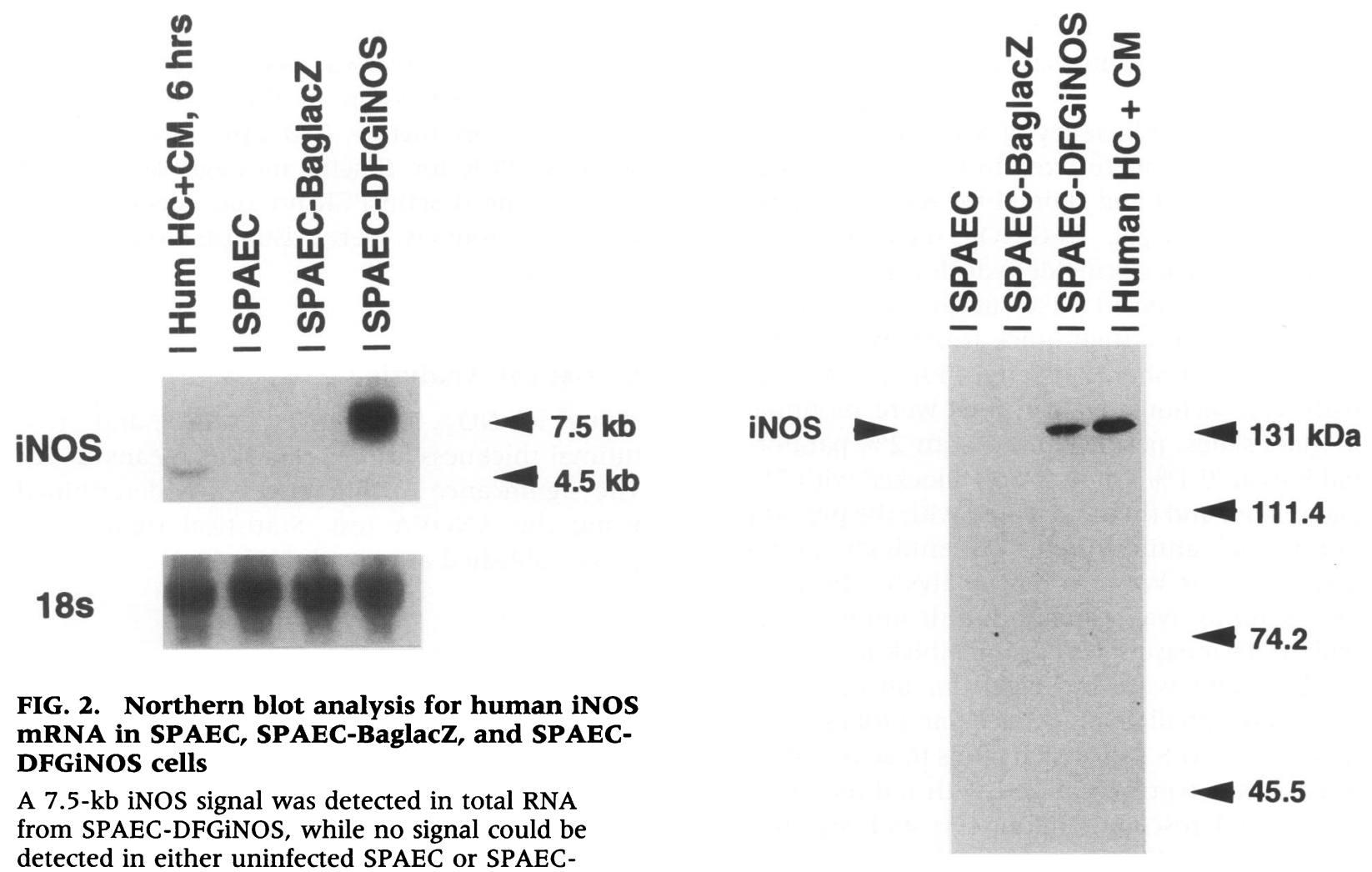

FIG. 2. Northern blot analysis for human iNOS mRNA in SPAEC, SPAEC-BaglacZ, and SPAECDFGiNOS cells

A 7.5-kb iNOS signal was detected in total RNA from SPAEC-DFGiNOS, while no signal could be detected in either uninfected SPAEC or SPAECBaglacZ. The endogenous human hepatocyte iNOS mRNA in cytokine-stimulated human hepatocytes (Hum HC + CM, $6 \mathrm{hr}$ ) measures $4.5 \mathrm{~kb}$ in size.

supplementation was found to be adequate to optimize iNOS activity.

\section{Transfer and Expression of Human iNOS in Vascular Endothelial Cells}

To assess endothelial cells as a potential vascular target for stable iNOS gene transfer, SPAECs were infected with the high titer DFGiNOS supernatant and selected in G418. By Northern blot analysis (Fig. 2), high levels of iNOS mRNA were found in SPAEC-DFGiNOS but not in either uninfected or BaglacZ control groups. The iNOS mRNA in SPAEC-DFGiNOS migrated at $7.5 \mathrm{~kb}$, distinct from the $4.5-\mathrm{kb}$ size of endogenous human hepatocyte iNOS mRNA and corresponded to the expected size for the polycistronic DFGiNOS retroviral transcript. No 4.5-kb signal was detected in any of the SPAEC groups. Stimulation of SPAEC with cytokine combinations effective in inducing iNOS expression in other cell types failed to yield detectable levels of sheep iNOS mRNA (B. R. Pitt, unpublished data). Western blot analysis of SPAEC lysates (Fig. 3)

demonstrated the presence of iNOS protein in SPAEC-DFGiNOS cytosolic preparations, similar in mobility to endogenous human iNOS protein in cytosol from cytokine treated human hepatocytes (31).

$\mathrm{NO}_{2}^{-}$production (representing $40 \%$ of total nitrogen oxide metabolites) by uninfected and BaglacZ- and DFGiNOS-infected SPAEC is summarized in Fig. 4. SPAEC-DFGiNOS produced $155.0 \pm 10.7 \mathrm{nmol} / \mathrm{mg}$ protein $/ 24 \mathrm{hr}$ compared with $5.5 \pm 1.1$ by SPAEC-BaglacZ and $6.4 \pm 1.1$ by uninfected cells $(p<0.01)$. Nitrogen oxide synthesis by these cells was inhibited by the addition of L-NMA to the culture medium. Supplemental $\mathrm{BH}_{4}$ did not significantly increase $\mathrm{NO}_{2}^{-}$ production, unlike the CRIP cells that had been dependent on added cofactor. The results indicate these proliferating vascular endothelial cells can express and support a functional human iNOS enzyme and that such cells could produce sufficient $\mathrm{BH}_{4}$ to support NO synthesis activity. 


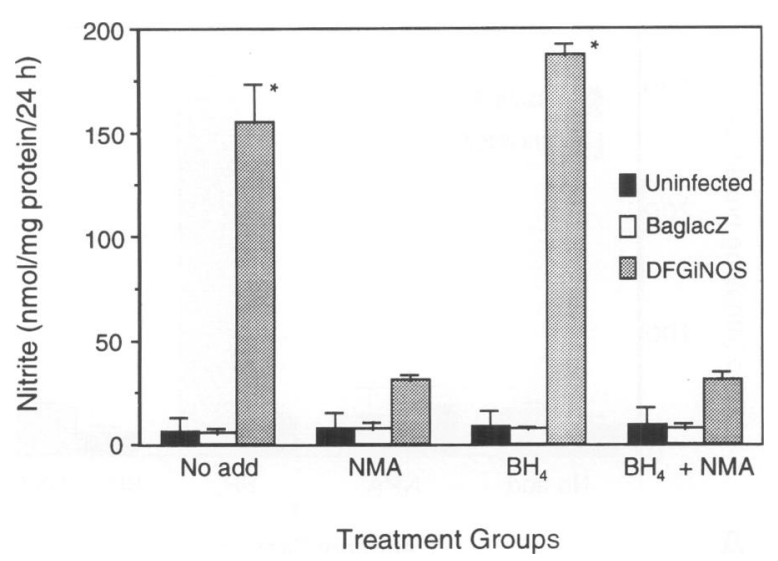

FIG. 4. Comparison of $\mathrm{NO}_{2}^{-}$production by uninfected SPAEC, SPAEC-BaglacZ, and SPAECDFGiNOS

Each bar represents the mean $\pm \mathrm{SD}(n=3$ for each group, experiments were repeated three or more times with comparable results). L-NMA was added at $0.5 \mathrm{mM}$ concentrations, while $\mathrm{BH}_{4}$ was supplemented at $100 \mu \mathrm{M} .{ }^{*} p<0.01$ versus uninfected $\pm \mathrm{L}-\mathrm{NMA}, \pm \mathrm{BH}_{4}$ and BaglacZ $\pm_{\mathrm{L}-\mathrm{NMA}} \pm \mathrm{BH}_{4}$ by ANOVA.

The expression of ecNOS is important to normal endothelial function. Therefore, the effect of sustained supraphysiologic NO synthesis by iNOS on endogenous ecNOS expression in these endothelial cells was also examined. Northern blot analysis (Fig. 5A) revealed that steady-state ecNOS mRNA levels were not significantly altered in SPAEC-DFGiNOS maintained with or without L-NMA for greater than 14 days compared with native SPAEC. Similarly, exposure of SPAEC to the exogenous NO donor SNAP (1 $\mathrm{mM}$ ) for $6 \mathrm{hr}$ resulted in a 1.5-fold increase in ecNOS mRNA versus SPAEC treated with the parent compound. Levels of ecNOS protein did not vary between protein isolated from whole cell preparations of uninfected SPAEC, SPAECDFGiNOS maintained in L-NMA, or SPAECDFGiNOS grown in the absence of L-NMA (Fig. $5 B)$. ecNOS protein was not detectable in the cytosolic fractions from these groups (data not shown). Thus, stable expression of iNOS had minimal effects on ecNOS mRNA and protein levels.

\section{Transfer and Expression of Human iNOS in Vascular Smooth Muscle Cells}

The ability of RSMC, another vascular target cell, to support a foreign iNOS enzyme was also ex-
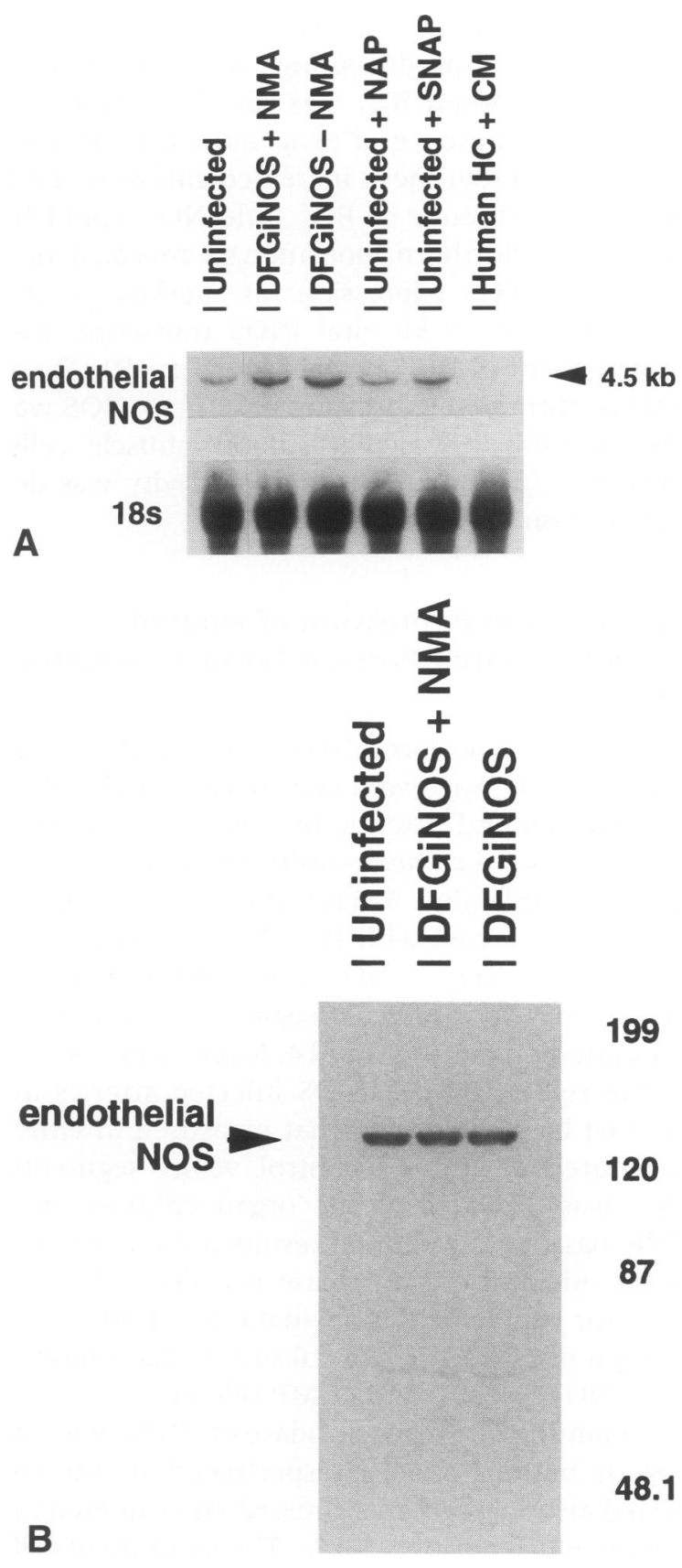

199

120

87

48.1

FIG. 5. Effect of iNOS gene transfer on ecNOS expression in SPAECs

(A) Northern blot analysis for ecNOS mRNA in total RNA samples from SPAEC, SPAEC-DFGiNOS grown in the presence of $0.5 \mathrm{mM}$ L-NMA, SPAEC-DFGiNOS grown without iNOS inhibition for greater than 7 days, SPAEC exposed to $1 \mathrm{mM}$ SNAP for $6 \mathrm{hr}$, and SPAEC exposed to $1 \mathrm{mM}$ NAP for $6 \mathrm{hr}$. Human hepatocytes (HC) stimulated with a mixture of cytokines (30) serves as a negative control. (B) Western blot analysis for ecNOS protein expression in whole cell preparations of SPAEC, SPAEC-DFGiNOS cultured in L-NMA (SPAEC-DFGiNOS + NMA), and SPAEC-

DFGiNOS permitted to synthesize NO for $>7$ days (SPAEC-DFGiNOS). 
amined. In contrast to SPAEC, RSMC transduced with DFGiNOS produced high levels of nitrogen oxides only when $\mathrm{BH}_{4}$ was supplemented (Fig. $6 \mathrm{~A})$. In the presence of exogenous $\mathrm{BH}_{4}, \mathrm{RSMC}$ DFGiNOS NO synthesis increased almost 10 -fold, but in the absence of $\mathrm{BH}_{4}$ little $\mathrm{NO}_{2}^{-}$could be measured. Northern blot analysis revealed that retroviral iNOS expression, as marked by the characteristic $7.5-\mathrm{kb}$ viral iNOS transcript, was independent of $\mathrm{BH}_{4}$ availability (Fig. 6B). These data confirm that expression of human iNOS was also feasible in vascular smooth muscle cells; however, functional enzymatic activity was dependent on exogenous $\mathrm{BH}_{4}$.

\section{Transfer and Expression of Human iNOS to Injured Porcine Femoral Arteries in Vitro}

The ability to perform iNOS gene transfer to arterial vessels was evaluated in vitro with intact porcine femoral arteries in organ culture. Following balloon catheter-induced vascular injury and viral infection 5 days after injury, arterial segments infected with DFGiNOS released 3- to 4 -fold more $\mathrm{NO}_{2}^{-}+\mathrm{NO}_{3}^{-}$versus uninjured vessels or MFGlacZ-infected segments (Table 1) as measured on culture Day 14. More dramatically, cGMP release by DFGiNOS infected arteries increased by 15 -fold over that measured in either uninjured or injured control vessel segments. $\mathrm{BH}_{4}$ was provided to the organ cultures on a daily basis because initial results indicated nitrogen oxide and cGMP release was dependent on cofactor supplementation (data not shown). Inclusion of L-NMA in the culture media inhibited both $\mathrm{NO}_{2}^{-}+\mathrm{NO}_{3}^{-}$and cGMP release.

Staining for $\beta$-galactosidase or iNOS (Fig. 7A, top or bottom panels, respectively) in the infected arterial segments showed an estimated infection efficiency of $0.5-1 \%$. The majority of cells expressing either enzyme were found to be located in the superficial neointimal region. While the viral infection efficiency appeared extremely low, earlier attempts to infect similar arterial segments not subjected to prior injury resulted in no detectable transgene expression. Because of this low efficiency, transgene expression was further confirmed by reverse transcriptase PCR amplification for human iNOS message. The predicted 316-bp iNOS PCR product was strongly detected only in DFGiNOS-infected vessel segments (Fig. 7B). A very low level of iNOS mRNA was detected in MFGlacZ-infected vessels. While the iNOS PCR primers did not amplify rodent iNOS
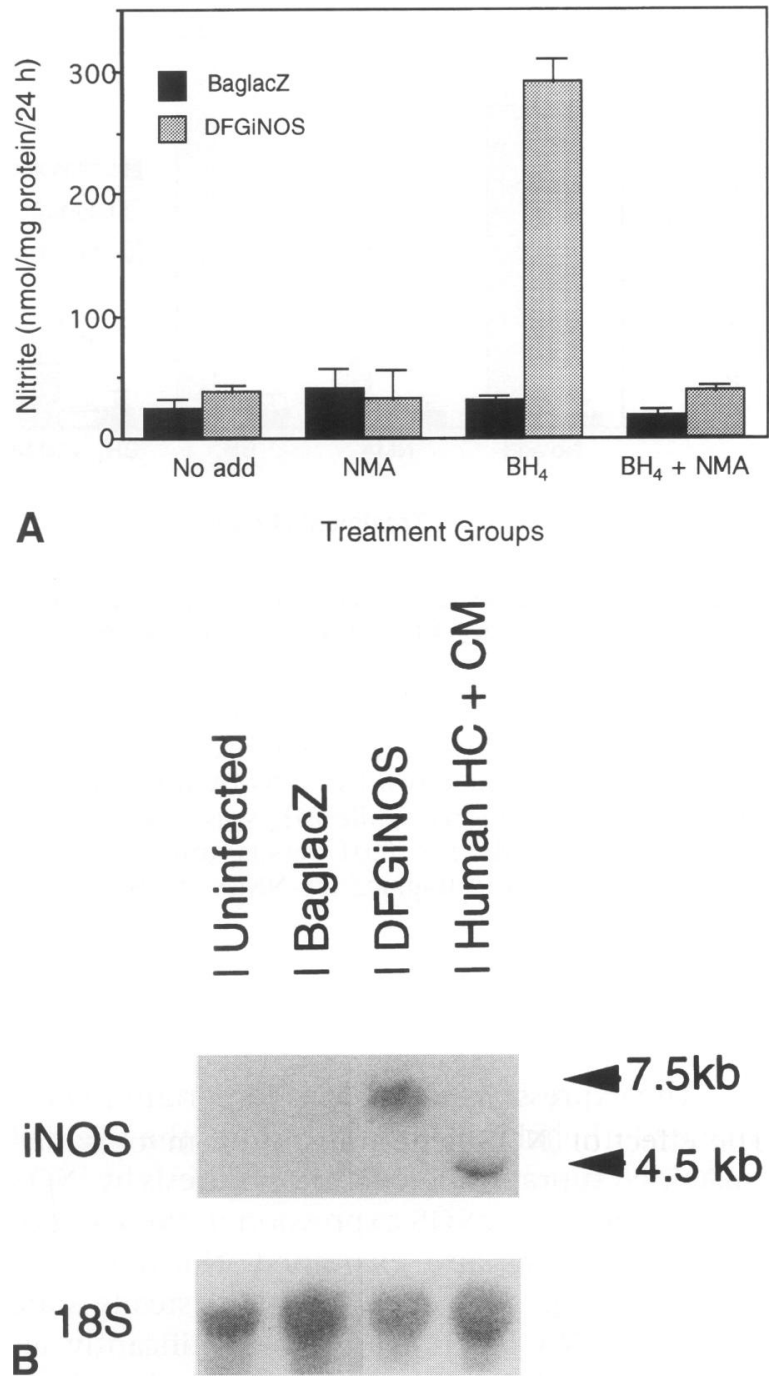

FIG. 6. Characterization of iNOS expression and activity in transduced RSMCs

(A) $\mathrm{NO}_{2}^{-}$production as measured by the Griess reaction in uninfected, BaglacZ, and DFGiNOS RSMCs. Each bar represents the mean $\pm \operatorname{SD}(n=3$, each experiment repeated three times). iNOS activity was measured $\pm_{\mathrm{L}}-\mathrm{NMA}(0.5 \mathrm{mM}), \pm \mathrm{BH}_{4}$ $(100 \mu \mathrm{M}) .{ }^{*} p<0.01$ versus uninfected and BaglacZ cells by ANOVA. (B) Northern blot analysis for human iNOS mRNA in RSMC, RSMC-BaglacZ, and RSMC-DFGiNOS cells. A 7.5-kb iNOS signal was detected in total RNA from RSMC-DFGiNOS only. The endogenous human hepatocyte iNOS mRNA from cytokine stimulated human hepatocytes (Hum $\mathrm{HC}+\mathrm{CM}, 6 \mathrm{hr}$ ) measures $4.5 \mathrm{~kb}$.

sequences (data not shown), there may be some cross-reactivity with porcine iNOS sequences. Detectable iNOS expression by PCR amplification in control vessels may reflect a low level induction secondary to balloon catheter injury (39). 
TABLE 1. Total nitrogen oxide and cGMP production by porcine arterial segments

\begin{tabular}{|c|c|c|c|c|}
\hline Treatment Groups & $\begin{array}{l}\text { Total } \mathrm{NO}_{2}^{-} \text {and } \mathrm{NO}_{3}^{-} \\
\quad(\mathrm{pmol} / \mathrm{mg} / 24 \mathrm{hr})\end{array}$ & $\begin{array}{r}p \text { Value }^{a} \\
(\text { ANOVA) }\end{array}$ & $\begin{array}{c}\text { cGMP } \\
(\mathrm{fmol} / \mathrm{mg} / 24 \mathrm{hr})\end{array}$ & $\begin{array}{r}p \text { Value }^{\ddagger} \\
\text { (ANOVA) }\end{array}$ \\
\hline Control & $29.7 \pm 6.5^{b}$ & - & $5.2 \pm 2.8$ & - \\
\hline Injury alone & $35.4 \pm 8.4$ & $\mathrm{NS}^{c}$ & $7.3 \pm 3.4$ & NS \\
\hline Injury + MFGlacZ & $40.1 \pm 5.2$ & NS & $6.8 \pm 2.9$ & NS \\
\hline Injury + DFGiNOS & $121.9 \pm 43.1$ & 0.001 & $101.3 \pm 12.1$ & 0.002 \\
\hline Injury + DFGiNOS + L-NMA & $37.4 \pm 8.2$ & NS & $5.6 \pm 4.2$ & NS \\
\hline
\end{tabular}

${ }^{a}$ Versus uninjured control arterial segments.

${ }^{b}$ Values are means $\pm \mathrm{SD}, n=4$, representative of three separate experiments.

NS, not significant.

However, amplification for Neo sequences (Fig. 7B), unique to the DFGiNOS retrovirus, revealed expression solely in the DFGiNOS-infected vessels and provides additional confirmation of expression of the transfered genes.

\section{Effect of Human iNOS Gene Transfer on Myointima Formation}

The effect of iNOS gene transfer on myointimal proliferation in response to injury was evaluated and is summarized in Fig. 8A. Balloon catheter injury resulted in a significant increase in myointimal thickness, as determined by rhodamine phalloidan staining (Fig. 8B), in both injury alone or injury followed by infection with MFGlacZ (myointimal thicknesses of 153 and $147 \%$ of uninjured controls, respectively). In contrast, the proliferative response to balloon injury in arteries subsequently infected with DFGiNOS was markedly attenuated and essentially indistinguishable from uninjured vessels. The inhibitory effect of DFGiNOs infection on myointimal thickening was completely abrogated by L-NMA administration, indicating the effect was dependent on NO synthesis. These results show successful reduction in myointimal hypertrophy following balloon catheter-induced arterial injury with human iNOS gene transfer despite low gene transfer efficiency.

\section{DISCUSSION}

This study represents our initial investigation into the feasibility and biologic effectiveness of vascular human iNOS gene transfer. We con- structed a retroviral vector carrying a functional human iNOS cDNA that was used to genetically modify vascular endothelial cells and smooth muscle cells to stably express iNOS. The DFGiNOS-transduced endothelial cells produced 30 -fold more NO than native cells in an autonomous fashion. In contrast, smooth muscle cells required exogenous $\mathrm{BH}_{4}$ to support NO synthesis. $\mathrm{BH}_{4}$ is an essential cofactor for all NOS isoforms. We have shown that NIH3T3 cells engineered to stably express human iNOS express both mRNA and protein in the absence of exogenous $\mathrm{BH}_{4}$ but only exhibits iNOS activity when $\mathrm{BH}_{4}$ is added to the cells (37). $\mathrm{BH}_{4}$ addition is associated with a conversion of intracellular iNOS protein from inactive monomers to active dimers (37). De novo $\mathrm{BH}_{4}$ synthesis is controlled by the rate-limiting enzyme GTP cyclohydrolase I (21). Select cells possess basal levels of $\mathrm{BH}_{4}$ synthesis to support enzymes such as phenylalanine hydroxylase (40) while other cells, including fibroblasts $(21,37)$ and vascular smooth muscle cells (41), are known to lack constitutive GTP cyclohydrolase I expression and activity. In some cells, co-induction of GTP cyclohydrolase I along with iNOS occurs in response to cytokine stimulation. This co-induction serves as a mechanism to ensure sufficient $\mathrm{BH}_{4}$ to support the induced NOS activity $(21,41) . \mathrm{BH}_{4}$ is present in endothelial cells to support ecNOS function and, therefore, most likely permits these cells to support a transfered iNOS enzyme without additional $\mathrm{BH}_{4}$; resting smooth muscle cells lack $\mathrm{BH}_{4}$ synthesis and, in the absence of cytokine stimulation, would be expected to be dependent on exogenous $\mathrm{BH}_{4}$ to activate the foreign iNOS protein. Thus, stable transfer of the human iNOS 
a
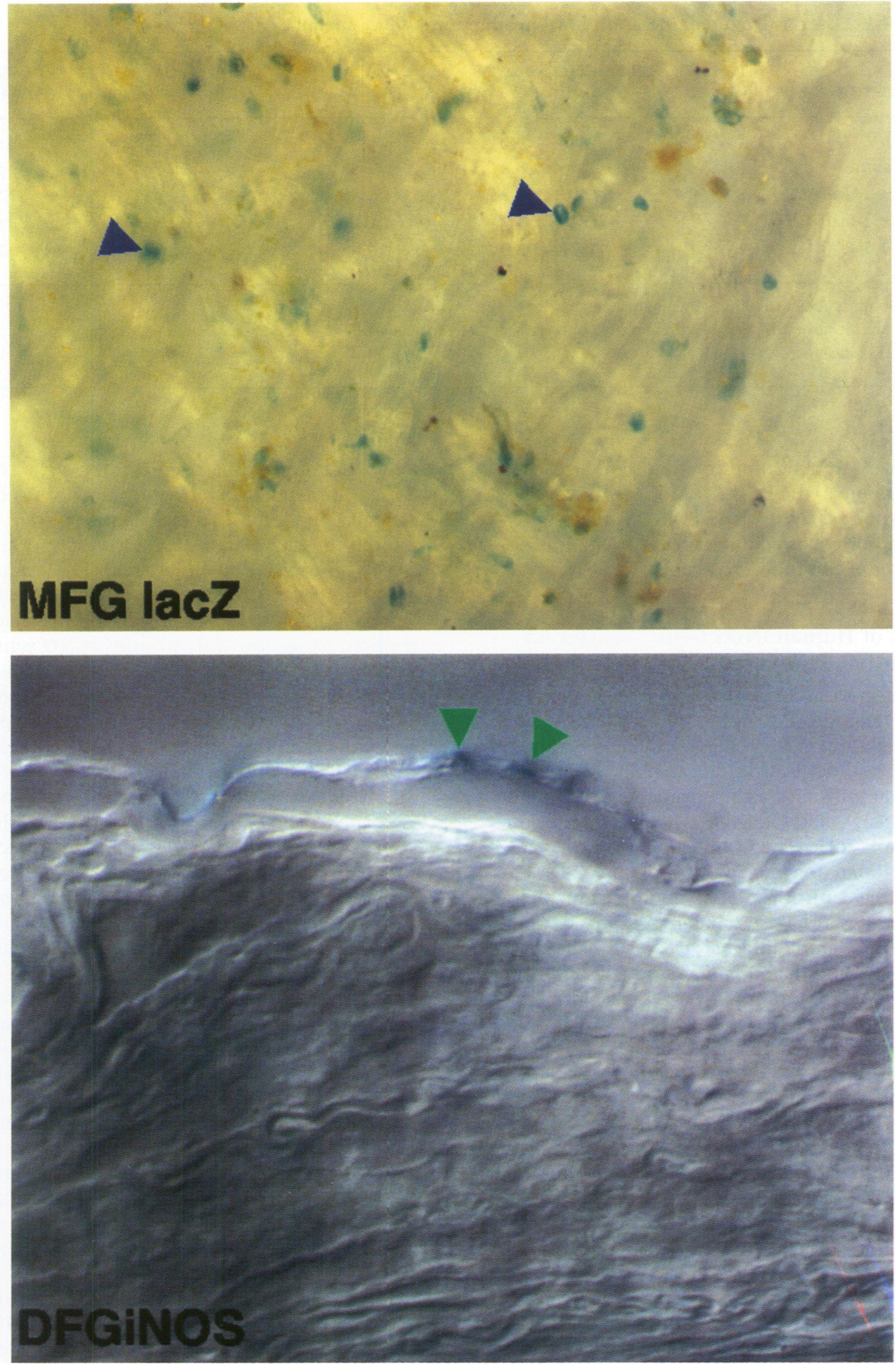


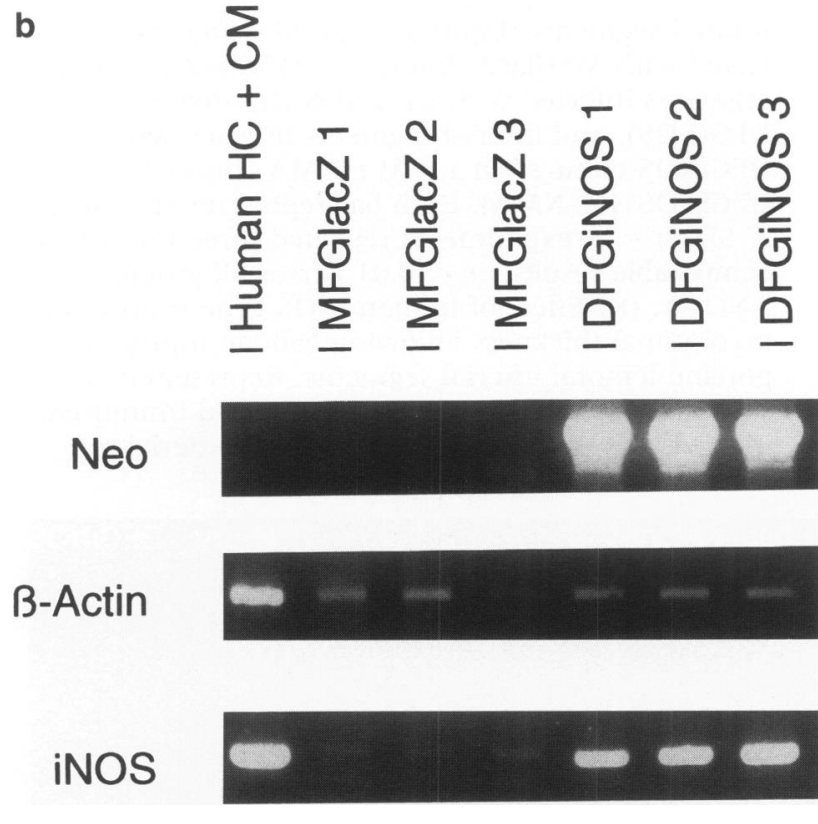

gene to naive vascular target cells utilizing a retroviral vector can be achieved, but iNOS activity is intimately linked to cofactor availability in the targeted cells.

The biologic effect of human iNOS gene transfer on myointimal thickening was assessed in an ex vivo organ culture system. Balloon catheter-induced arterial injury elicits a characteristic tissue response consisting of smooth muscle migration, proliferation, and augmented extracellular matrix deposition. These events culminate in neointima formation and myointimal thickening. An in vitro model of vascular injury using rabbit aorta with subsequent gene transfer has been established (35) and has been shown to be useful in studying the effect of various gene products on intimal hyperplasia. We adapted this model to balloon catheter-injured porcine femoral arteries where a similar injury response was reproducibly created. Human iNOS gene transfer to these injured vessel segments was accomplished with retroviral infection 5 days post-injury, a time period associated with near-maximal smooth muscle cell proliferation (35). Because of the absolute requirement for cellular replication for successful retroviral integration, infection of uninjured vessels or vessels immediately following injury resulted in poor infection efficiencies. By delaying infection until maximal cellular pro-
FIG. 7. Expression of human iNOS in injured porcine femoral arteries in vitro

(A) Upper panel, X-gal staining for $\beta$-galactosidase activity in MFGlacZ-infected arterial segments. Blue arrows, positively staining (blue) cells located in superficial layers as viewed from the lumenal surface. Estimated infection efficiency about $1 \%$. Lower panel, Immunolocalization for iNOS protein in DFGiNOSinfected arterial segments in cross section. Green arrows, positively staining cells which are isolated to the thin neointimal layer. No such staining is evident in the media. (B) Reverse transcriptase PCR amplification for iNOS and Neo expression in MFGlacZ- and DFGiNOS-infected balloon catheter-injured porcine femoral arterial segments 9 days after infection with ret652 bp roviral vectors. The iNOS PCR product measures $316 \mathrm{bp}$, while the Neo product measures $728 \mathrm{bp}$. Reverse transcriptase PCR was also performed for $\beta$-actin expression as a control for the first strand 316 bp cDNA synthesis reaction and PCR amplification (PCR product $652 \mathrm{bp}$ ). liferation was achieved, our infection efficiency was improved to $1 \%$. While this still represents a small number of cells expressing the transgene, NO synthesis and cGMP production were nonetheless significantly elevated. Despite the low efficiency of gene transfer, the level of iNOS expression and NO synthesis was sufficient to eliminate the myointimal hyperplasia associated with the vascular injury response. It is not surprising that sufficient levels of NO were synthesized by the few infected cells to dramatically influence CGMP and myointimal proliferation in vitro. NO is highly diffusable in solution and creates a "field effect" around secreting cells (42). In the absence of hemoglobin, NO would be expected to have profound effects on neighboring cells. Whether such an extensive field effect will be available in vivo remains to be determined.

The mechanism by which NO impacts on myointimal thickening and which aspects of smooth muscle migration, proliferation, and extracellular matrix deposition that iNOS gene transfer influences remains to be elucidated. While higher levels of NO release significantly reduced $\left[{ }^{3} \mathrm{H}\right]$-thymidine incorporation (9), our early observations indicate that the levels of $\mathrm{NO}$ generated by the DFGiNOS-infected arterial segments have minimal effects on smooth muscle 

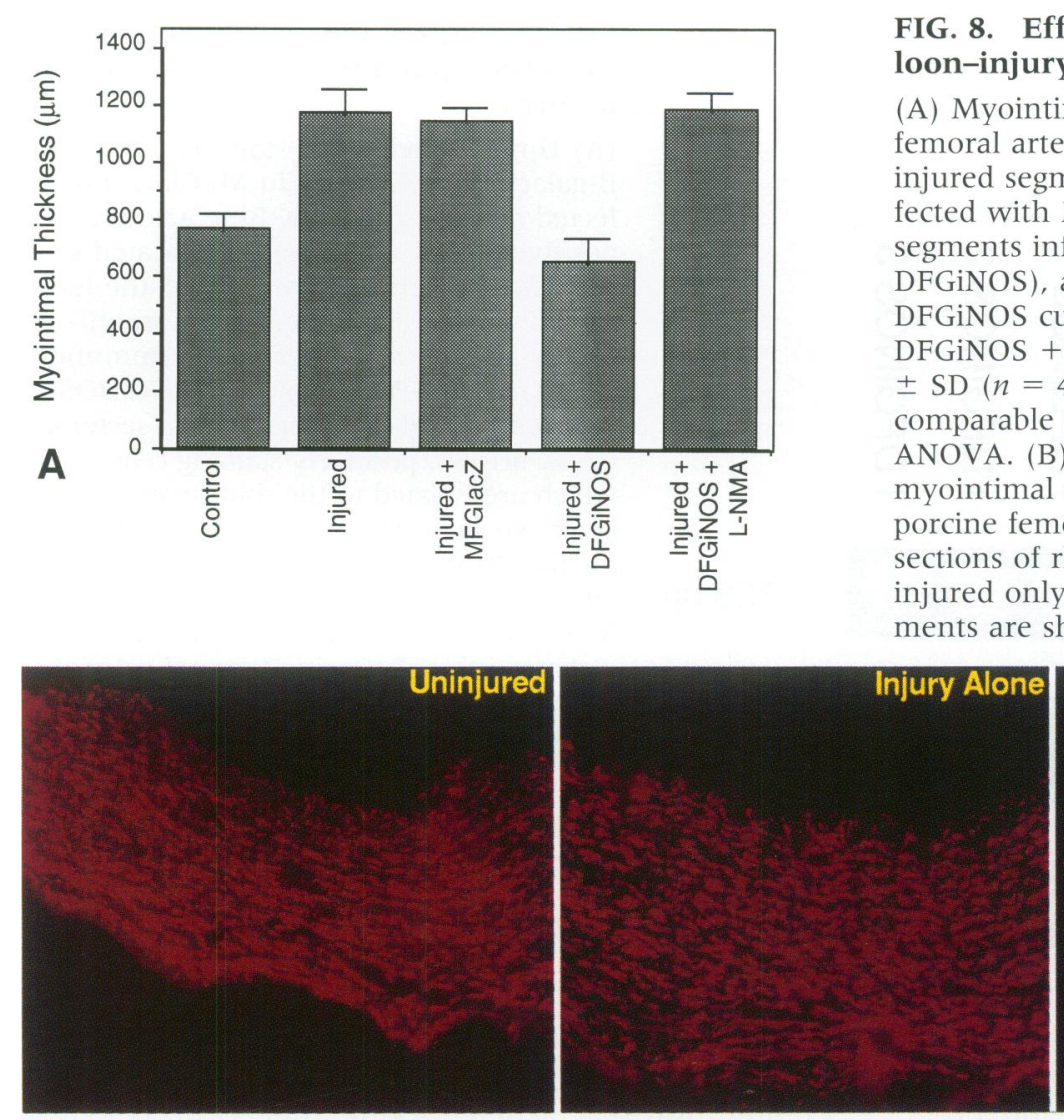

B

cell proliferation in cell culture (E. Tzeng, unpublished data). Alternatively, NO may be interfering with the synthesis of extracellular matrix components such as collagen and elastin. Strauss et al. (43) reported that cellular proliferation in myointimal lesions in a rabbit model of restenosis was modest and peaked in the first week while extracellular matrix deposition remained significantly elevated and continued to contribute to the thickening process for up to 4 weeks. Thus, in our model of arterial injury, iNOS gene transfer and NO synthesis may be acting through the inhibition of extracellular matrix synthesis by the smooth muscle cells. Indeed, we have demonstrated that cells stimulated to express iNOS or exposed to NO exhibit a marked reduction in protein synthesis $(34,44)$.

Based on our in vitro observations, the requirement for $\mathrm{BH}_{4}$ for increased NO synthesis in this arterial injury and gene transfer model suggests that iNOS gene transfer primarily targeted the vascular smooth muscle cells. This was confirmed by immunohistochemistry showing both lacZ and iNOS expression localized to the myointima. If a similar distribution of expression
FIG. 8. Effect of iNOS gene transfer on balloon-injury myointima formation

(A) Myointimal thickness of uninjured porcine femoral artery segments (Control), balloon catheterinjured segments (Injured), injured segments infected with MFGlacZ (Injured + MFGlacZ), injured segments infected with DFGiNOS (Injured + DFGiNOS), and injured segments infected with DFGiNOS cultured in $1 \mathrm{mM}$ L-NMA (Injured + DFGiNOS + L-NMA). Each bar represents the mean $\pm \mathrm{SD}(n=4$, experiments repeated three times with comparable results. ${ }^{*} p<0.01$ versus all groups by ANOVA. (B) Effect of human iNOS gene transfer on myointimal thickness following balloon injury of porcine femoral arterial segments. Representative sections of rhodamine phalloidin-stained uninjured, injured only, and injured + DFGiNOS arterial segments are shown. Magnification: $10 \times$.

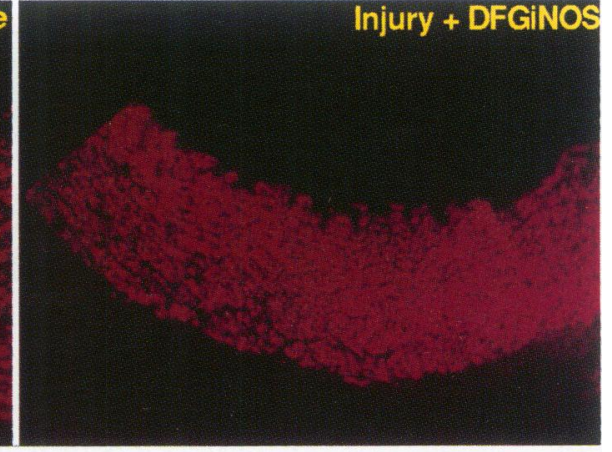

were to occur in vivo, a means to simultaneously increase $\mathrm{BH}_{4}$ availability would be required. Possibilities include administration of exogenous $\mathrm{BH}_{4}$ or $\mathrm{BH}_{4}$ substrates (e.g., sepiapterin) or cotransfer of the gene for GTP cyclohydrolase I, the rate-limiting enzyme for $\mathrm{BH}_{4}$ biosynthesis.

Recent observations suggest that reduced NO availability may contribute to the progression of atherosclerotic disease and to the complications of therapeutic vascular intervention $(15,16)$ as a result of the loss of the antithrombogenic and antiproliferative influences of NO. Previous data from others $(17,18)$ and our current data suggests that restoring NO levels in diseased vasculature may have therapeutic efficacy. Interestingly, endothelial injury induces the expression of an endogenous iNOS in rat vascular smooth muscle cells (39), increasing NO production at the site of injury. Smooth muscle iNOS expression in this setting may represent an adaptive mechanism derived to prevent acute thrombosis and intimal hyperplasia at sites of injury until endothelial integrity is reestablished. This iNOS expression, however, is transient, persisting for a 1 - to 2-week period, while the healing process 
continues for many weeks, and may explain the failure of this endogenous iNOS expression to limit intimal lesion formation. Prevention of intimal hyperplasia with iNOS gene transfer may require that gene expression persist for several weeks if not longer. Current methods of gene delivery only offer a single option that permits long-term transgene expression, that of retroviral-mediated gene transfer. The low efficiency of retroviral gene transfer limits its utility, but our data suggest the potential for therapeutic success despite low levels of iNOS expression.

Support for both the importance of NO for restoring normal structure and function of the blood vessel wall and for the therapeutic use of NOS gene transfer to reduce restenosis comes from von der Leyen et al. (19). These authors show inhibition of intimal hyperplasia and restoration of vasoreactivity in a rat carotid artery injury model using liposome-mediated transfer of the bovine endothelial cNOS. In clinical practice, high efficiency vascular gene transfer may be difficult due to the dangers of prolonged vascular occlusion required by most gene transfer techniques. Our studies suggest that iNOS may have some advantages over ecNOS. Because iNOS activity is not dependent on increases in intracellular calcium levels for activation, the activity of the expressed enzyme will be dependent only on cofactor and substrate availability, as shown by our studies in cells and tissue, and not agonists to increase intracellular free calcium. Furthermore, because the activity of iNOS is much greater than ecNOS, the transfer efficiency required for production of therapeutic levels of NO may be much lower than for ecNOS. With continued, rapid advances in vector and delivery system development for vascular gene therapy, specific approaches for adequate and safe transfer of NOS to blood vessels may soon be a reality.

\section{ACKNOWLEDGMENTS}

We would like to acknowledge the excellent technical assistance of Ms. Lori McKenzie, Ms. Solthi Tran, and Mr. Paul Moyer, as well as Dr. Laurence Zitvogel for helpful discussion. This work was supported in part by National Institutes of Health Grants GM-44100 (TRB), GM37753 (RLS), DK-44935 (PDR), HL-32154 (BRP), and F32-GM-16645 (ET). TRB is the recipient of the George H. A. Clowes Jr., M.D., Memorial Research Career Development Award of the American College of Surgeons.

\section{REFERENCES}

1. Ross R. (1993) The pathogenesis of atherosclerosis: A perspective for the 1990's. Nature 362: 801-809.

2. Powel JS, Clozel JP, Muller RK, et al. (1989) Inhibitors of angiotension-converting enzyme prevent myointimal proliferation after vascular injury. Science 245: 186-188.

3. Simons M, Edelman ER, DeKeyser JL, Langer RS, Rosenberg RD. (1992) Antisense c-myb oligonucleotides suppress smooth muscle accumulation in vivo. Nature 359: 6770.

4. Ohno T, Gordon D, San H, et al. (1994) Gene therapy for vascular smooth muscle cell proliferation after arterial injury. Science 265: 781-784.

5. Chang MW, Barr E, Seltzer J, et al. (1995) Cytostatic gene therapy for vascular proliferative disorders with a constitutively active form of the retinoblastoma gene product. Science 267: 518-522.

6. Ignarro LJ, Buga GM, Wood KS, Byrns RE, Chaudhuri G. (1987) Endothelium-derived relaxing factor produced and released from artery and vein is nitric oxide. Proc. Natl. Acad. Sci. U.S.A. 84: 9265-9269.

7. Palmer RMJ, Ferrige AG, Moncada S. (1987) Nitric oxide release accounts for the biological activity of endothelium-derived relaxing factor. Nature 327: 524-527.

8. Mellion BT, Ignarro LJ, Ohlstein EH, Pontecarvo EG, Hyman AL, Kadowitz PJ. (1981) Evidence for the inhibitory role of guanosine $3^{\prime}: 5^{\prime}$-monophosphate in ADP induced human platelet aggregation in the presence of nitric oxide and related vasodilators. Blood 57: 946-955.

9. Garg UC, Hassid A. (1989) Nitric oxide-generating vasodilators and 8-bromo-cyclic guanosine monophosphate inhibit mitogenesis and proliferation of cultured rat vascular smooth muscle cells. J. Clin. Invest. 83: 17741777.

10. Kubes P, Suzuki M, Granger DN. (1991) Nitric oxide: An endogenous modulator of leukocyte adhesion. Proc. Natl. Acad. Sci. U.S.A. 88: 4651-4655.

11. Mayer B, Schmidt K, Humbert P, Böhme E. (1989) Bissynthesis of endothelium-derived relaxing factor: A cytosolic enzyme in porcine aortic endothelial cells $\mathrm{Ca}^{2+}$-dependently converts L-arginine into an activation 
of soluble guanylyl cyclase. Biochem. Biophys. Res. Commun. 164: 678-685.

12. Busse R, Mülsch A. (1990) Calcium-dependent nitric oxide synthesis in endothelial cytosol is mediated by calmodulin. FEBS Lett. 265: 133-136.

13. Linder L, Kiowski W, Buhler FR, Luscher TF. (1990) Indirect evidence for release of endothelium-derived relaxing factor in human forearm circulation in vivo. Blunted response in essential hypertension. Circulation 81: 1762-1767.

14. Panza JA, Quyyumi AA, Brush Jr JE, Epstein SE. (1990) Abnormal endothelium-dependent vascular relaxation in patients with essential hypertension. N. Engl. J. Med. 323: 22-27.

15. O'Donohoe MK, Murchan PM, Marks P, Feely J, Feeley TM. (1993) Endotheliumderived relaxing factor is absent in experimental in situ vein grafts. Eur. J. Vasc. Surg. 7: $144-150$.

16. Chester AH, O'Neil GS, Moncada S, Tadjkarimi S, Yacoub MH. (1990) Low basal and stimulated release of nitric oxide in atherosclerotic epicardial coronary arteries. Lancet 336: 897-900.

17. McNamara DB, Bedi B, Aurora $\mathrm{H}$, et al. (1993) L-arginine inhibits balloon catheterinduced intimal hyperplasia. Biochem. Biophys. Res. Commun. 193: 291-296.

18. Davies MG, Kim JH, Dalen H, Makhoul RG, Svendsen E, Hagen PO. (1994) Reduction of experimental vein graft intimal hyperplasia and preservation of nitric oxide-mediated relaxation by the nitric oxide precursor Larginine. Surgery 116: 557-568.

19. von der Leyen HE, Gibbons GH, Morishita R, et al. (1995) Gene therapy inhibiting neointimal vascular lesions: In vivo transfer of endothelial cell nitric oxide synthase gene. Proc. Natl. Acad. Sci. U.S.A. 92: 1137-1141.

20. Morris Jr SM, Billiar TR. (1994) New insights into the regulation of inducible nitric oxide synthesis. Am. J. Physiol. 266: E829-E839.

21. Werner-Felmayer E, Werner ER, Fuchs D, Hausen A, Reibnegger G, Wachter H. (1990) Tetrahydrobiopterin-dependent formation of nitrite and nitrate in murine fibroblasts. $J$. Exp. Med. 172: 1599-1607.

22. Geller DA, Lowenstein CJ, Shapiro RA, et al. (1993) Molecular cloning and expression of inducible nitric oxide synthase from human hepatocytes. Proc. Natl. Acad. Sci. U.S.A. 90: 3491-3495.
23. Dranoff G, Jaffee EM, Lazenby A, et al. (1993) Vaccination with irradiated tumor cells engineered to secrete murine GMCSF stimulates potent, specific and long lasting antitumor immunity. Proc. Natl. Acad. Sci. U.S.A. 90: 3539-3543.

24. Zitvogel L, Tahara H, Cai Q, et al. (1994) Construction and characterization of retroviral vectors expressing biologically-active human interleukin-12. Human Gene Ther. 5: 1493-1506.

25. Price J, Turner D, Cepko C. (1987) Lineage analysis in the vertebrate nervous system by retrovirus-mediated gene transfer. Proc. Natl. Acad. Sci. U.S.A. 84: 156-160.

26. Pear WS, Nolan GP, Scott ML, Baltimore D. (1993) Production of high titer helper-free retroviruses by transient transfection. Proc. Natl. Acad. Sci. U.S.A. 90: 8392-8396.

27. Danos O, Mulligan RC. (1988) Safe and efficient generation of recombinant retroviruses with amphotropic and ecotropic host ranges. Proc. Natl. Acad. Sci. U.S.A. 85: 64606464.

28. Danos O. (1991) Construction of retroviral packaging cell lines. In: Collins $\mathrm{M}$ (ed). Methods in Molecular Biology, Vol. 5: Practical Molecular Virology, Viral Vectors for Gene Expression. Humana Press, Clifton, NJ, pp. 17-27.

29. Davies P, Patton W. (1994) Peripheral and central vascular smooth muscle cells from rat lung exhibit different cytoskeletal protein profiles but similar growth factor requirements. J. Cell. Physiol. 159: 399-406.

30. Chomczynski P, Sacchi N. (1987) Single step method of RNA isolation by acid guanidium thiocyanate-phenol-chloroform extraction. Anal. Biochem. 162: 156-159.

31. Geller DA, Nussler AK, DiSilvio $M$, et al. (1993) Cytokines, endotoxin, and glucocorticoids regulate the expression of inducible nitric oxide synthase in hepatocytes. Proc. Natl. Acad. Sci. U.S.A. 90: 522-526.

32. Luss $\mathrm{H}$, DiSilvio $M$, Litton AL, Molina y Vedia L, Nussler AK, Billiar TR. (1994) Inhibition of nitric oxide synthesis enhances the expression of inducible nitric oxide synthase mRNA and protein in a model of chronic liver inflammation. Biochem. Biophys. Res. Commun. 204-2: 635-640.

33. Laemmli UK. (1970) Cleavage of structural proteins during the assembly of the head of bacteriophage T4. Nature 227: 680-685.

34. Billiar TR, Curran RD, Stuehr DJ, West MA, Bentz BG, Simmons RL. (1989) An L-argi- 
nine-dependent mechanism mediates Kupffer cell inhibition of hepatocyte protein synthesis in vitro. J. Exp. Med. 169: 1467-1472.

35. Takeshita S, Gal D, Leclerc G, et al. (1994) Increased gene expression after liposomemediated arterial gene transfer associated with intimal smooth muscle cell proliferation: In vitro and in vivo findings in a rabbit model of vascular injury. J. Clin. Invest. 93: 652-661.

36. Baek KJ, Thiel BA, Lucas S, Stuehr DJ. (1993) Macrophage nitric oxide synthase subunits: Purification, characterization, and role of prosthetic groups and substrates in modulating their association into a dimeric enzyme. J. Biol. Chem. 268: 21120-21129.

37. Tzeng E, Billiar TR, Robbins PD, Loftus $M$, Stuehr DJ. (1995) Expression of human inducible NO synthase in a tetrahydrobiopterin-deficient cell line: tetrahydrobiopterin promotes assembly of enzyme subunits into an active dimer. Proc. Natl. Acad. Sci. U.S.A. 92: 11771-11775.

38. Croen KD. (1993) Evidence for antiviral effect of nitric oxide. Inhibition of herpes simplex type 1 replication. J. Clin. Invest. 91: 2446-2456.

Contributed by E. Beutler on December 18, 1995.
39. Hansson GK, Geng Y, Holm J, Hardhammar P, Wennmalm A, Jennische E. (1994) Arterial smooth muscle cells express nitric oxide synthase in response to endothelial injury. $J$. Exp. Med. 180: 733-738.

40. Kaufman S. (1963) The structure of phenylalanine hydroxylation cofactor. Proc. Natl. Acad. Sci. U.S.A. 50: 1085-1093.

41. Nakayama DK, Geller DA, DiSilvio M, et al. (1994) Tetrahydrobiopterin synthesis and inducible nitric oxide production in pulmonary artery smooth muscle. Am. J. Physiol. 266: L455-L460.

42. Lancaster Jr JR. (1994) Simulation of the diffusion and reaction of endogenously produced nitric oxide. Proc. Natl. Acad. Sci. U.S.A. 91: 8137-8141.

43. Strauss BH, Chisholm RJ, Keeley FW, Gotleib AI, Logan RA, Armstrong PW. (1994) Extracellular matrix remodeling after balloon angioplasty injury in a rabbit model of restenosis. Circ. Res. 75: 650-658.

44. Curran RD, Ferrari FK, Kispert PH, et al. (1991) Nitric oxide and nitric oxide-generating compounds inhibit hepatocyte protein synthesis. FASEB J. 5: 2085-2092. 